\title{
Development of a biodiesel activity
}

Oléagineux, Corps Gras, Lipides. Volume 8, Numéro 1, 33-8, Janvier - Février 2001, Dossier : Deutsche Gesellschaft für Fettwissenschaft - Association française pour l'étude des corps gras

Auteur(s) : Georges VERMEERSCH, Sofiproteol, 12, avenue George-V, 75008 Paris, France.

Résumé : Les différents éléments ayant conduit à un développement significatif d'une activité biodiesel en France seront examinés : organisation de la filière oléagineuse, partenariat avec les pétroliers, accompagnement des pouvoirs publics en termes réglementaires et fiscaux... II sera ensuite procédé à un état des lieux de l'outil de transestérification français. Les avantages du biodiesel, fonctionnalité et qualités environnementales, seront présentés à la lumière de récents résultats expérimentaux. Après description des voies d'utilisation du biodiesel par les pétroliers, le positionnement de celui-ci dans un nouvel environnement (spécifications des carburants, moteurs HDI et post-traitement) sera discuté.

Mots-clés : biodiesel, développement français, avantages, utilisations.

Summary : The circumstances that led to the significant French biodiesel activity will be examined: the oilseed producers and transformers actions, the partnership with the oil refiners, the government support - regulation and detaxation... The French production units will be described, followed by update scientific results highlighting the advantages of biodiesel: functionality and friendly environmentally impact. The current usage of biodiesel by oil refiners will be described and its future in the oncoming context (fuel specifications, HDI engines and post-treatment) discussed.

Keywords : biodiesel, development in France, advantages, usage.

\section{ARTICLE}

As an introduction to this talk, I will quickly mention the factors that have made for a significant development of a biodiesel activity in France.

I will then go on to review the current status from the agricultural and industrial standpoints.

After setting out a few functional and environmental advantages of biofuel, I will present its two avenues of use.

I will conclude by mentioning the situation of biofuel within a new statutory and technical framework. 


\section{Background}

In the mid 1980s, the French oil-yielding plant sector endeavoured to find new markets for rapeseed oils which were under-used in the food sector at European level.

Having mentioned the French oil-yielding sector, I should briefly define it. It includes four structures:

* FOP, which represents all oil- and protein crops producers,

* Cetiom, Centre technique des oléagineux (oil crops agronomic institute),

* Onidol, an interprofessional organization that includes all the participants: from seed producers through to end users including crushers,

* Sofiproteol, the sector's financial company.

The oil-yielding plant sector has made a dominant contribution to the development of a biodiesel activity.

It had initially been envisaged to use crude oil to produce diesel fuel. While this is technically feasible with diesel engines, it cannot be put into generalised use because of certain physical/chemical characteristics that are very different from those of diesel fuel [1].

It should also be noted that the oil cannot be distilled at normal pressure as it cracks.

On the other hand, rapeseed oil methyl esters have very similar physical/chemical characteristics to diesel fuel (Table 1).

We then entered into a partnership with the Institut français du Pétrole which was developing a novel process for the transesterification of plant oils for fuel use: the ESTERFIP process.

This partnership involved the usual stages in industrial development:

- the laboratory,

- the $1 \mathrm{~m}^{3}$ pilot scheme installed in Compiègne,

- the demonstration unit with a capacity of 20,000 metric tons/year, built in 1992 and operational in 1993, also located in Compiègne.

In parallel with this industrial development, the oil-yielding plant sector became involved in a vast test programme to validate a diesel fuel containing $5 \%$ biofuel.

Indeed, the strategy we adopted was to use the product in a blended rather than pure form, which thus called for a partnership with oil producers.

We opted for this solution as a $5 \%$ blend can be used on any vehicle without calling for technical modifications, which thus opens up a large-scale market.

This comprehensive programme took place from 1991 to 1995 in two stages, and was coordinated by the IFP. All the structures concerned took part in these trials: the oil-yielding plant sector of course, the oil producers Elf et Total, the engine manufacturers Renault, Peugeot and Renault Véhicules 
industriels, the public authorities via the Ministries of Agriculture and Industry, the Agence de l'environnement et de la maîtrise de l'énergie, and certain haulage contractors and public transport fleets.

The programme included tests:

- in the laboratory,

- on engine test benches,

- on a dynamometric chassis with light vehicles

- on the road on heavy-goods vehicles and light vehicles.

The conclusions of this vast trials programme, unique of its kind, has been that $5 \%$ biofuel has been able to be blended with diesel fuel on a generalised basis.

This blending strategy was able to be developed thanks to the statutory and fiscal support measures taken by French public authorities as and when data became available, from both the technical and macro-economic standpoints.

I will only outline here the most important decisions.

\section{Statutory measures}

Transitional decree of March 9, 1993

- $5 \%$ blend in diesel fuel subject to pump display.

\section{Decree of December 20, 1993}

- Generalised use of a less than 5\% blend from 1/04/94.

Decree of August 28, 1997

- New specifications for Fatty Acid Methyl Esters as a less than 5\% blend in diesel fuel and heating oil.

\section{Fiscal measures}

\section{Finance law for 1992}

- TIPP exemption for rapeseed and sunflower esters produced in pilot units approved and used as part of a trials programme. Valid up to 31/12/96.

\section{Finance law for 1993}

- Perpetuation of this exemption.

\section{Correction finance law for 1993}

- Upper limit of FFr 2.30/litre placed on exemption. 


\section{Correction finance law for 1997}

- Approval of FAME's production units as part of a European call for proposals.

\section{Situation in the year 2000}

\section{In agricultural terms}

Rapeseed for biofuel production now concerns an area of about 300,000ha in France (Figure 1).

This corresponds to a very significant development since the areas thus mobilised have been multiplied by 8 in the space of a few years.

The decrease in areas during some years is due to the fact that there are no specific regulations at European level concerning oil-yielding plant crops for the non-food sector.

Biofuel was developed in France and in Europe within a non-production framework: the energy set aside framework.

When the mandatory set aside ratio decreased some years, the areas intended for biofuel were lower (Table 2).

By the way, transesterification industries are embarrassed by such unstable supplies too.

\section{In industrial terms}

As I mentioned previously, to benefit from a suitable fiscal framework in France, biofuel must be produced by units approved by the public authorities following a European call for proposals.

The currently approved units are listed in Table 3.

The units located in France are shown in Figure 2.

The Grand-Couronne and Compiègne units belong to the oil-yielding plant sector and are operated by one of its subsidiaries, Diester industrie.

For the biofuel aspect, Diester industrie also operates, on a special order basis, the Boussens plant which belongs to the Cognis group.

Novaol, a subsidiary of the Eridania Beghin Say group, operates the Verdun plant, belonging to the Ici group.

In view of the biofuel rapeseed sowing intentions of agricultural producers, and the oil market demand, we consider the total approval of 317,500T to be insufficient.

We have thus requested an additional approval of $80,000 \mathrm{~T}$ from the public authorities. The file is being examined. 


\section{In commercial terms}

The marketable quantities have varied as follows over the last few years (Table 4):

- end of 1993: start up of the Compiègne demonstration unit,

- 1994: Novaol imports RMEs and adapts two units (Péronne and Verdun),

- end of 1995: start up of the Grand-Couronne unit,

- 1998: drop in consumption linked to the drop in production due to the set aside rate,

- the difference between approvals and consumption is due to approvals not fulfilled, differences between approvals and production, and between production and consumption.

\section{Advantages of biofuel}

While biofuel came about as a result of an agricultural problem, the functional and environmental assets of this product are now recognised and fully justify its development.

I do not intend to go into the upstream aspects in agricultural terms (rapeseed trapping nitrates) or the macro-economic aspects (employment, commercial balance) and will concentrate on the finished product only.

\section{Functional advantages}

\section{Lubricity}

Changes to the EN590 standard concerning diesel fuel quality will limit the sulphur content of diesel fuels to a maximum level of 50ppm in 2005 against 350ppm today.

The current experience concerning the use of diesel fuels with a low sulphur content shows that this entails risks of wear on the injection equipment of diesel vehicles.

In 1996, the IFP tested the wear-reduction effect of two types of biofuel in a Swedish city fuel with $10 \mathrm{ppm}$ of sulphur [2].

The method used is the HFRR (High Frequency Reciprocating Rig) test - a method accepted by the European Standardisation Committee - and the results are expressed in terms of mean wear diameter (Figure 3).

It is seen that, regardless of the type of ester used, a $2 \%$ blend of biofuel is sufficient for a diesel fuel with a very low sulphur content (10ppm) to meet the European standard of 460 mum.

\section{Carbon matter}

The Champagne céréales agricultural cooperative, located in Reims, runs some of the trucks of its fleet on a $50 \%$ diesel fuel- $50 \%$ biofuel blend. 
These trials vehicles are paired with reference vehicles running on diesel fuel, which are identical in terms of engines, vehicle age and the type of service provided.

By the end of 1999 , two trials vehicles had covered almost $500,000 \mathrm{~km}$ with the $50 \%$ blend.

The lubricating oil was analyzed at each oil change every $30,000 \mathrm{~km}$. The analysis focused on wear metals, carbon matter, viscosity at $40^{\circ} \mathrm{C}$ and $100^{\circ} \mathrm{C}$ and the TBN.

The results are the same for vehicles running on neat diesel fuel and vehicles running on a $50 \%$ blend, except for carbon matter for which there is a difference in favour of biofuel [3] (Table 5).

The decrease in the carbon matter index can be explained by the fact that it is known that biofuel produces fewer fumes.

This result is of interest, as carbon matter contributes to engine wear.

\section{Environmental advantages}

\section{Greenhouse effect}

Biofuel is a $90 \%$ renewable energy produced by photosynthesis using the carbon dioxide in the atmosphere.

According to a life cycle analysis carried out by the Ecobilan company validated by Ademe, $2.2 \mathrm{t}$ of equivalent $\mathrm{CO}_{2}$ are saved for each metric ton of biofuel used [4].

And this calculation does not take into account the portion of carbon fixed by the complete plant. If included, this would improve biofuel's $\mathrm{CO}_{2}$ results. Investigations are currently under way in France on this subject.

In monetary terms, according to the principle of negotiable permits based on a carbon savings assumption of euro $76 / \mathrm{t}$, i.e. euro $21 / \mathrm{t}$ of $\mathrm{CO}_{2}$, one metric ton of biofuel thus generates an external economy of euro 46.

\section{Statutory pollutants}

A very large number of investigations have shown the favourable effect of biofuel on polluting emissions.

I will only report here on the preliminary results of a test carried out by the IFP [5] on a heavy-goods vehicle engine meeting EURO2 standards the diesel fuel of which meets the requirements of the 2000 specifications.

The engine used is a RVI 620.45 .

The cycle is the ESC (European Steady-State Cycle).

The results are in Table 6. 
The following findings are obtained:

- no significant difference in terms of Nox,

- low, but significant drop in terms of $\mathrm{CO}$ and $\mathrm{HC}$,

- drop of about $20 \%$ in terms of particles and fumes.

With up-to-date fuel and engines, biofuel confirms its environmental advantages in terms of exhaust emissions.

\section{Biodegradability and ecotoxicity}

At the beginning of this year, we commissioned a specialised laboratory (BFB Oil Research) to carry out biodegradability and ecotoxicity analysis work on biofuel (RME) and on a reference diesel fuel NF-73-A-93 [6] (Table 7).

As far as the oral toxicity with regard to mammals is concerned, there appear to be no differences between biofuel and diesel fuel.

For the other toxicity tests, it is seen that diesel fuel always leads to worse results.

As far as the biodegradability measured over 28 days is concerned, the results obtained confirm the trends found in literature, namely the excellent biodegradability of biofuel $(>87 \%)$ against the very low biodegradability of diesel fuel (38.7\%).

After mathematical quantification, these tests estimate how harmful is a compound for water according to the Blue Angel standard.

Biofuel comes out with a mark of O ("generally not hazardous for water") whereas the reference diesel fuel, with a mark of 2 , is classified as "hazardous for water".

On the basis of these results and after additional trials on shrimps, the Centre de Documentation, de Recherche et d'Expérimentation sur les pollutions accidentelles des eaux (centre for documentation, research and trials for accidental water pollution), under the aegis of the Ministry for the Environment, has recommended the use of Diester to assist in cleaning rocks soiled by the Erika oil slick.

Total Fina Elf has also used biofuel to pump out Erika's tanks. It is used to fluidify the heavy fuel remaining in the tanks 120 metres below the surface of the sea in order to facilitate pumping out.

Once pumped up to the surface, the blend consisting of about $90 \%$ fuel oil and $10 \%$ biofuel is transferred to a shuttle petrol tanker.

Biofuel was then used during the final phase to recover the fuel oil trapped in the framework of the tanks. 


\section{Markets}

Given its functional and environmental advantages and our partnership strategy with oil companies, biofuel is proposed to the end consumer in two forms.

A standardised form that represents the majority of sales with a blend factor of between 2 and $3 \%$ for which its functional properties (lubricity) are sought.

A $30 \%$ blend for the public transport fleets of certain French towns where, in this case, its environmental properties are turned to better advantage.

Thirty or so cities using this blend have formed the Club des Villes Diester (Diester cities club, Figure 4).

The Diester designation being a registered trademark and representing an abbreviation of Diesel and Ester. It is now the term commonly used for biofuel in France.

\section{A new technical environment for biofuel}

With a view to fight with the pollution produced by transport vehicles, oil producers and engine manufacturers have, as a result of community work (Auto oil programme), significantly improved their products.

New specifications concerning fuels were published in 2000 , and other more restrictive specifications are due to come into force in 2005.

Engines are developed in accordance with the EURO 0-1-2-3-4, etc., standards and the marketing of $\mathrm{HDI}$ engines. And finally, post-treatment systems are being developed, in terms of both catalytic converters and particle filters.

How does biofuel perform in this new environment? This is what we are going to examine rapidly during the final part of this talk.

\section{New diesel fuel specifications}

Biofuel contains no polyaromatics and practically no sulphur. Its density is slightly higher.

Biofuel can thus provide a well adapted basis for formulating future fuels (Table 8).

\section{HDI power plant}

For the last 3 years, high pressure direct injection of the Common Rail type has become increasingly widespread. This new concept does, however, present many singularities: very high pressures in the rail (1,000-2,000 bars), fuel reaching high temperatures (possibly in excess of $120^{\circ} \mathrm{C}$ ), diesel fuel "compression/decompression" cycles, etc., that are operating particularities giving importance to certain characteristics of products: compressibility, viscosity, thermal stability and surface tension are examples of this.

The question as to whether biofuel was compatible with this new technology was thus justified. 
The French manufacturer PSA carried out numerous tests in the laboratory, on engine test benches and on the road with 5\% RME and 30\% RME. The conclusions of this investigation were that RME30 caused no operating problems with common rail engines.

The IFP, for its part, is currently carrying out additional work in this area with, among other things, a fuel containing $30 \%$ sunflower methyl ester, which is thus more unsaturated than RMEs.

\section{Particle filters (PF)}

After catalytic converters, another post-treatment is appearing on diesel vehicle, buses or light vehicles: particle filters.

Such filters such as those produced by Eminox use the catalytic conversion of $\mathrm{NO}$ into $\mathrm{NO}_{2}$ to allow them to be regenerated at reduced temperatures.

Considerations have been given as to whether biofuel could modify the working of PFs:

- either at the level of clogging itself,

- or modify the catalytic conversion of $\mathrm{NO}$ into $\mathrm{NO}_{2}$,

- or facilitate the ignition of trapped particles.

At the beginning of this year, we thus commissioned the French company CRMT to carry out a preliminary investigation with a $30 \%$ blend of RME [7].

The conclusions are that:

* in the case of an engine essentially emitting soot and not unburned hydrocarbons: the $30 \%$ blend of RME produces less soot, which decreases the filter's rate of clogging by a factor of about two (Figure 5);

* in the case of an engine emitting a large quantity of unburned hydrocarbons, the biofuel in the blend facilitates the regeneration of the soot $+\mathrm{HC}$ mixture retained in the PF (Figure 6).

Biofuel can thus be considered as an "additive" facilitating the regeneration of PFs under urban operating conditions.

\section{CONCLUSION}

The biodiesel activity has been set up in France and Europe in a short timescale. In addition to providing new markets for agriculture, this product has functional and environmental advantages. It is also fully compatible with future fuel/engine standards coming onto the market.

And finally, Fatty Acid Methyl Esters are going to open up new markets outside the diesel engine sector, both in solvents and lubricants. 


\section{REFERENCES}

1. MONTAGNE X (1996). Introduction of Rapeseed Methyl Ester in Diesel Fuel. The French National Program. SAE 962065.

2. MONTAGNE X (1996). Impact of RME on Diesel Fuel Lubricity (HFRR EVALUATION). 2nd European Motor Biofuels Forum. Graz, September 22-25, 1996.

3. GATEAU P, LAURENT YM, VERMEERSCH G (2000). Experiments incorporating raised contents of plant methyl esters in captive fleets of vehicles. Ademe intermediate report, Contract $n^{\circ}$ 97.01.058.

4. POITRAT E (1999). Biofuel and the greenhouse effect under French conditions. 3rd European Motor Biofuels Forum, Brussels, October 10-13, 1999.

5. RAUX S, MONTAGNE X (2000). Effect of the blending of plant oil esters on the non-statutory emissions of Diesel engines. IFP, 07/2000, Preliminary report.

6. VERMEERSCH G, COMBES A (2000). Up-dating of rapeseed methyl ester life cycle analysis and ability to biodegradation and ecotoxicological impact of some plant methyl esters. Rapport Ademe, Contrat $n^{\circ}$ 96.01.076.

7. DUCEUX JF, HAUPAIS A, LEPELTIER A (2000). Testing the regeneration of a particle filter with "sulphur-free" diesel fuel and rapeseed diester. CRMT - Ref. BCC324.00.671.A. 


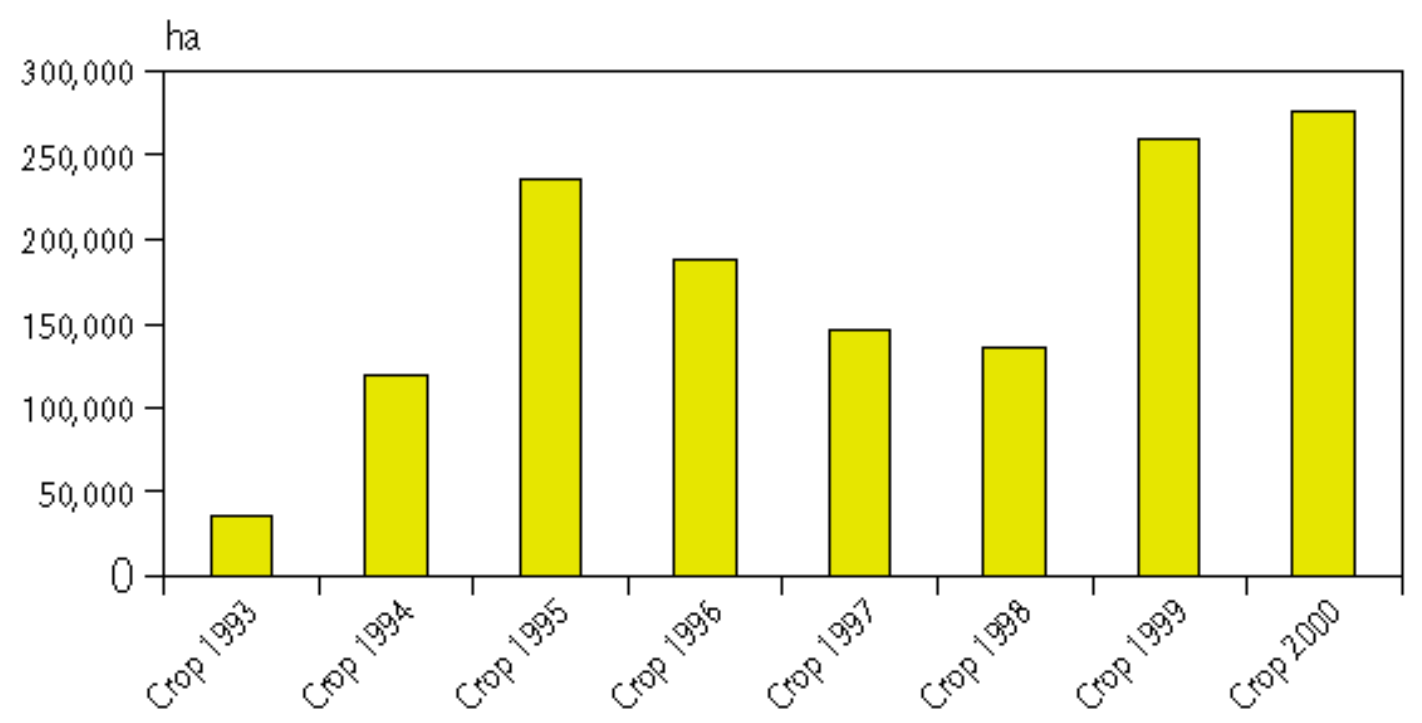

Figure 1. Cultivated areas destinated to biodiesel.

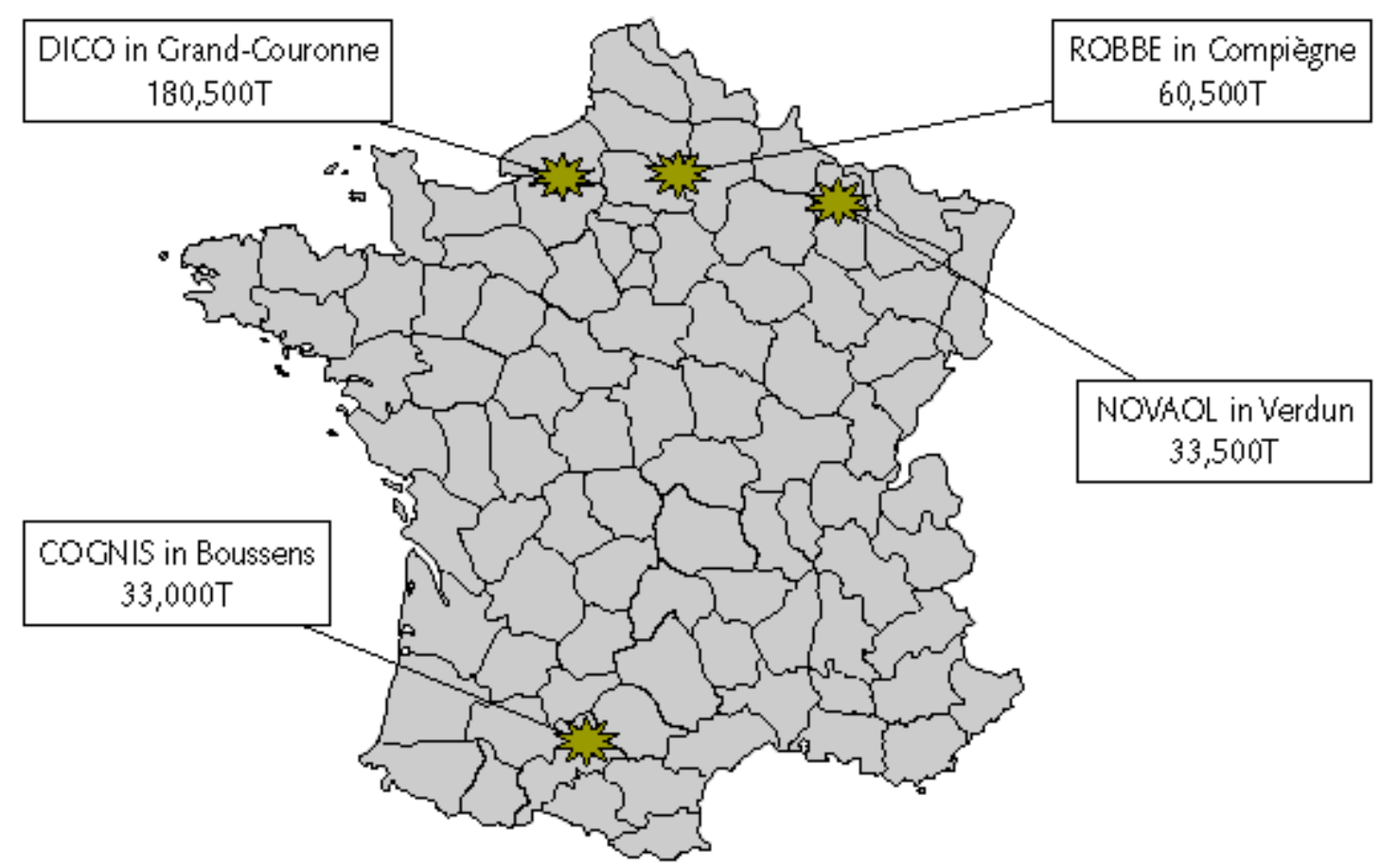

Figure 2. Units located in France. 


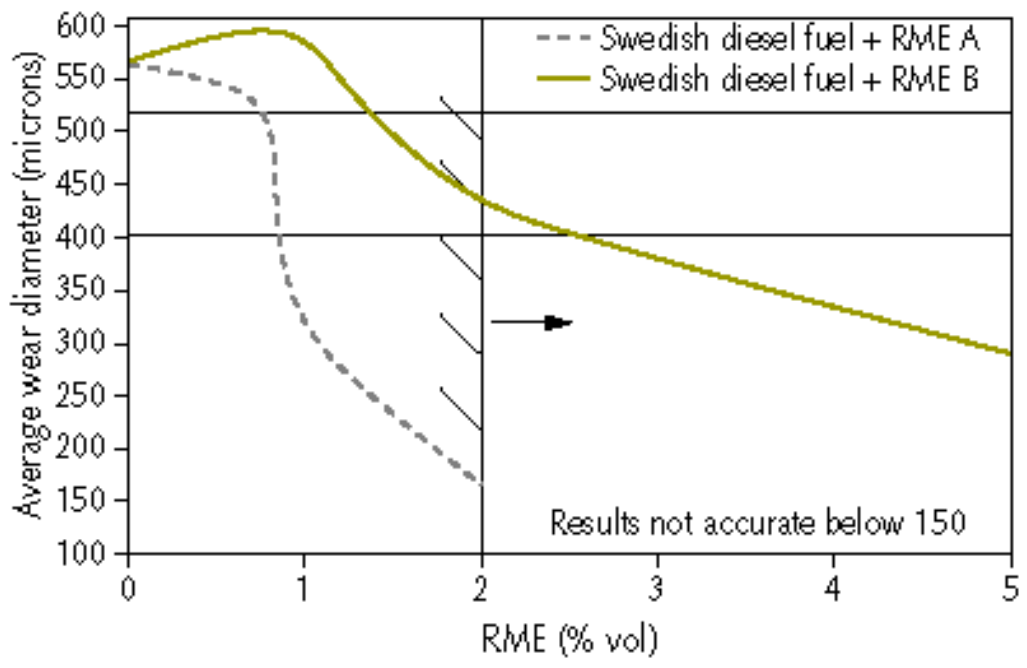

Figure 3. Effect of RME production process (HFRR results).

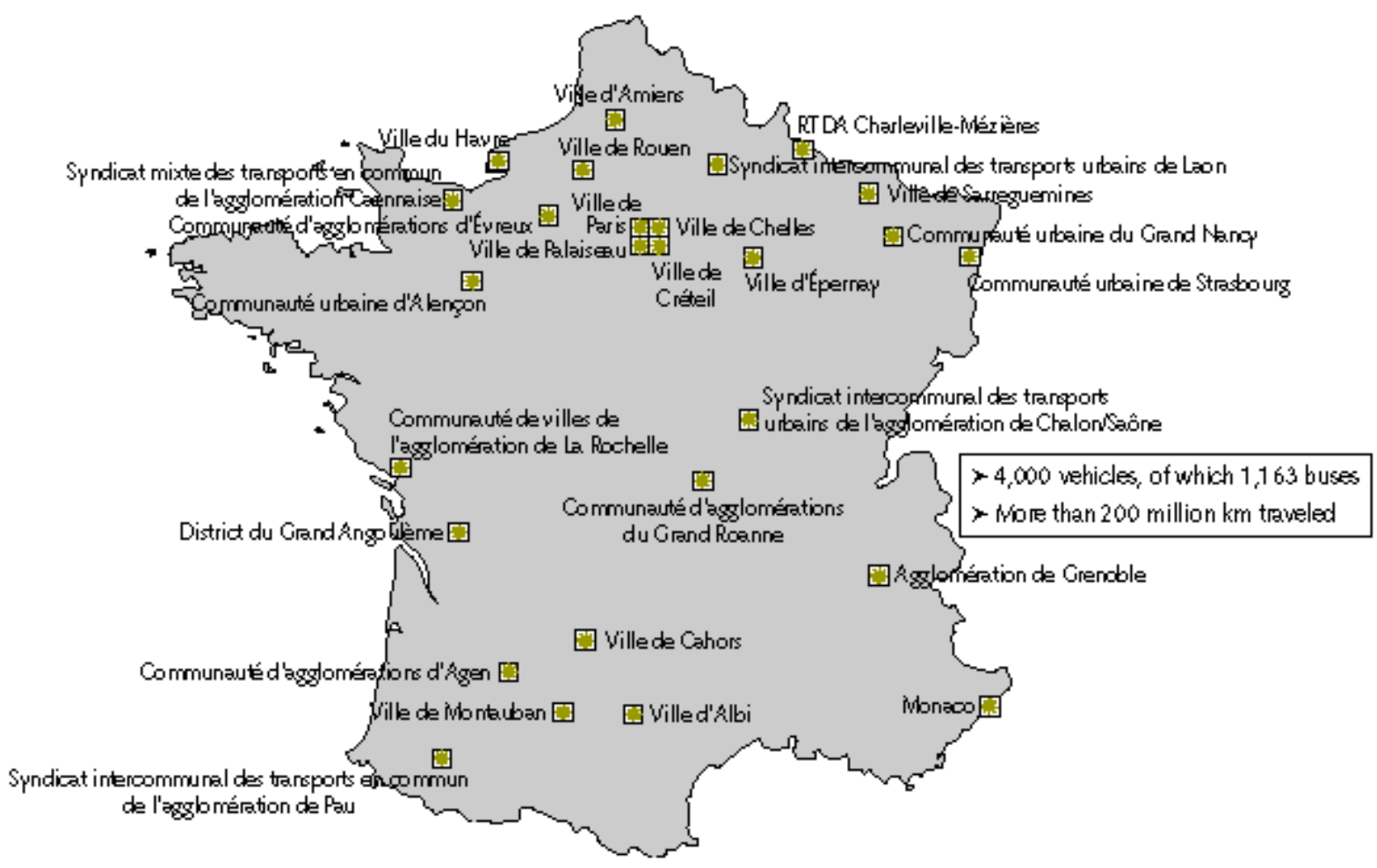

Figure 4. Diester cities club. 


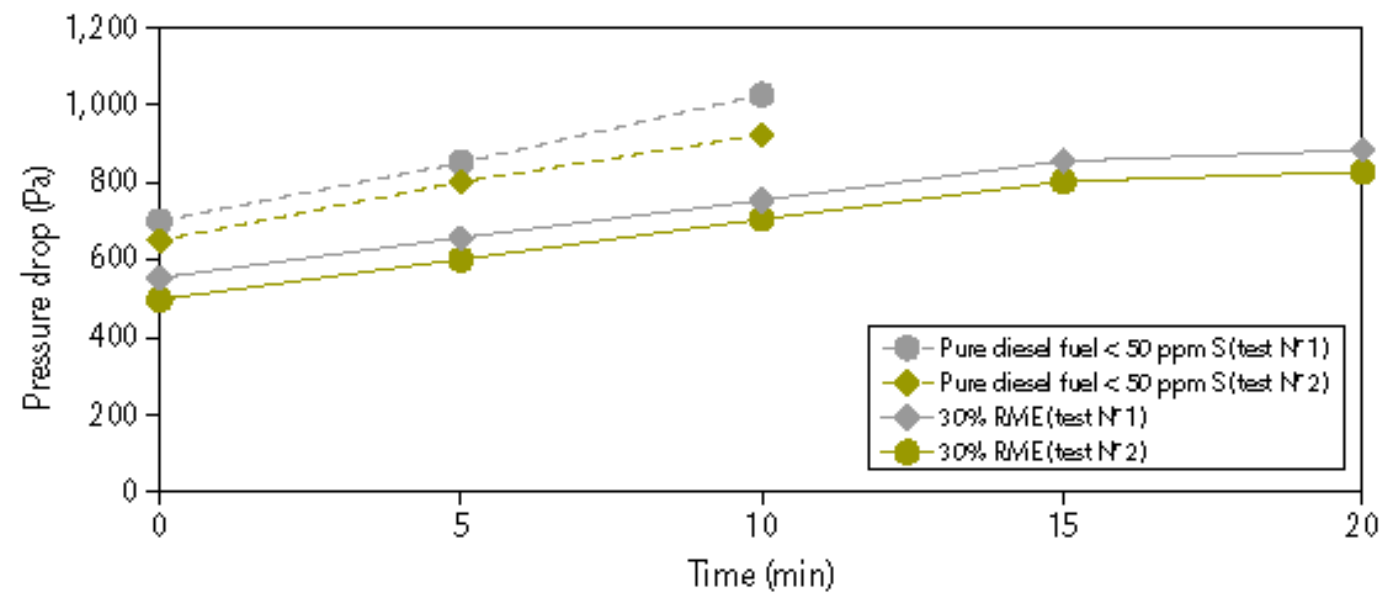

Pressure drop ( $\mathrm{Pa}$ ) during particulate accumulation at $600 \mathrm{rmm} \mathrm{4/4} \mathrm{charge}$

Figure 5. Particulate accumulation on Eminox trap.

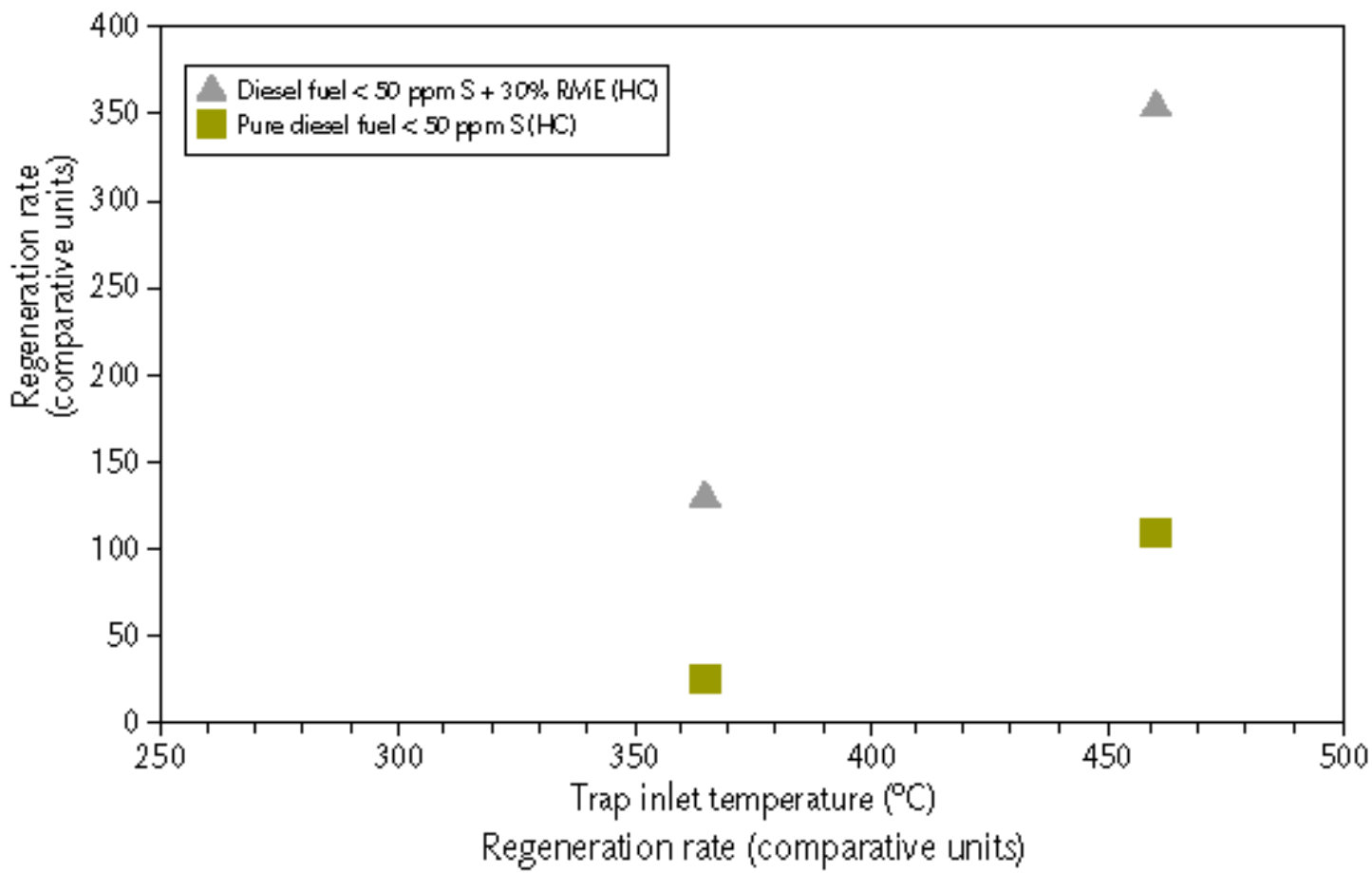

Figure 6. Eminox trap regeneration (after high HC level emission). 
Table 1. Main physico chemical characteristics of the fuels.

\begin{tabular}{l|c|c|c} 
Characteristics & Diesel fuel & Rapeseed oil & Rapeseed methyl ester \\
\hline Specific gravity $\left(\mathrm{kg} / \mathrm{m}^{3}\right)$ & $820-860$ & 920 & $880-885$ \\
$40^{\circ} \mathrm{C}$ viscosity $\left(\mathrm{mm}^{2} / \mathrm{s}\right)$ & $2-4.5$ & 30.2 & 4.5 \\
Cetane nu mber & $>49$ & 35 & 50
\end{tabular}

- Specificatiors prior to 01/01/2000.

Source IFP.

Table 2. Evolution of the set-aside rate.

\begin{tabular}{|l|c|c|c|c|c|c|c|c}
\hline & 1993 & 1994 & 1995 & 1996 & 1997 & 1998 & 1999 & 2000 \\
\hline Set aside rate (\%) & 15 & 15 & 12 & 10 & 5 & 5 & 10 & 10
\end{tabular}

Table 3. Industrial approvals in 2000 .

\begin{tabular}{l|r}
\multicolumn{1}{c|}{ Plant } & Approwal \\
\hline Cognis in Boussens & $33,000 \mathrm{~T}$ \\
Robbe in Compiegne & $60,500 \mathrm{~T}$ \\
Dico in Grand-Couronne & $180,500 \mathrm{~T}$ \\
Novaol in Verdun & $33,500 \mathrm{~T}$ \\
Connemann in Leer & $10,000 \mathrm{~T}$ \\
Total & $\mathbf{3 1 7 , 5 0 0 T}$
\end{tabular}

Table 4. Biofuel marketing.

\begin{tabular}{|r|r|}
1992 & $700 \mathrm{~T}$ \\
1993 & $7,800 \mathrm{~T}$ \\
1994 & $64,100 \mathrm{~T}$ \\
1995 & $152,900 \mathrm{~T}$ \\
1996 & $215,900 \mathrm{~T}$ \\
1997 & $246,400 \mathrm{~T}$ \\
1998 & $225,100 \mathrm{~T}$ \\
1999 & $264,400 \mathrm{~T}$
\end{tabular}

Source Customs. 
Table 5. Mean of the analysis resuits for all oil changes.

\begin{tabular}{l|c|c} 
Vehic les & Number of analysis samples & Carbon matter \\
\hline Scania 50\% biofuel & 15 & 0.40 \\
Scania diesel fuel & 15 & 0.51 \\
Volvo 50\% biofuel & 18 & 1.62 \\
Volvo diesel fuel & 16 & 1.86
\end{tabular}

Table 6. Statutory pollutants.

\begin{tabular}{|l|c|c|c|c|c}
\hline Fuel & Nox & Co' & HC' & Particles $^{1}$ & Fumes $^{2}$ \\
\hline Pure Euro 2000 diesel fuel & 6.09 & 0.41 & 0.31 & 0.0613 & 0.744 \\
Blend of 70\% Euro 2000 & 5.83 & 0.36 & 0.27 & 0.0499 & 0.593 \\
diesel fuel and 30\% biofuel & & & & & \\
$\%$ & -4.3 & -12.2 & -12.9 & -18.6 & -20.3 \\
\hline
\end{tabular}

'Ing/kWh.

${ }^{2}$ Bosch units.

Table 7. Ecoto xicity and biodegradability.

\begin{tabular}{l|c|c|c} 
Test earried out & Units & Biofuel & Refere nce diesel fuel \\
\hline $\begin{array}{l}\text { Oral toxicity on mammals } \\
\text { OCDE } 401\end{array}$ & LD50 (mg/kg) & $>5,000$ & $>5,000$ \\
$\begin{array}{l}\text { Toxicity on bacteria } \\
\text { ISO } 10712\end{array}$ & ECO (mg/l) & 5,250 & $<10$ \\
$\begin{array}{l}\text { Toxicity on fish } \\
\text { OCDE 203 } \\
\text { Biodegradability } \\
\text { OCDE 301B }\end{array}$ & $\%$ LC50 (mg/l) & $>100,000$ & 134 \\
\end{tabular}

Table 8. New diesel fuel specification.

\begin{tabular}{|c|c|c|c|}
\hline & \multicolumn{2}{|c|}{ Diesel fuel spec ifications } & \multirow[b]{2}{*}{ Biofuel } \\
\hline & Current $(01 / 01 / 00)$ & 2005 & \\
\hline Sulphur (ppm) & 350 & 50 & 10 \\
\hline Polyaromatics $(\% \mathrm{~m} / \mathrm{m})$ & $\max .11$ & & 0 \\
\hline Density $\left(\mathrm{kg} / \mathrm{m}^{3}\right)$ & $820-845$ & & 880 \\
\hline Measured cetane & 51 & & 50 to 53 \\
\hline T95 ("C) & 370 & & 345 \\
\hline
\end{tabular}

